\title{
Modeling of Solar Drying Economics Using Life Cycle Savings (L.C.S) Method
}

\author{
Oyetunde Adeoye Adeaga1*, Ademola Adebukola Dare2, Kamilu Moradeyo Odunfa², \\ Olayinka Soledayo Ohunakin ${ }^{3}$ \\ ${ }^{1}$ Department of Mechanical Engineering, The Polytechnic, Ibadan, Adeseun Ogundoyin Campus, Eruwa, Nigeria \\ ${ }^{2}$ Department of Mechanical Engineering, University of Ibadan, Ibadan, Nigeria \\ ${ }^{3}$ Department of Mechanical Engineering, Covenant University, Otta, Nigeria \\ Email: engr.adeaga@gmail.com
}

Received 23 February 2015; accepted 8 August 2015; published 11 August 2015

Copyright (C) 2015 by authors and Scientific Research Publishing Inc.

This work is licensed under the Creative Commons Attribution International License (CC BY).

http://creativecommons.org/licenses/by/4.0/

(c) $\underset{\mathrm{EY}}{(-)}$ Open Access

\begin{abstract}
Major goals of industrialization include but are not limited to provision of employment, establishing a platform for overall national development and improving the capital income of whoever is involved, which invariably improve the overall standard of living. A better pre-visibility study must encompass a well analyzed economic appraisal of the plan. The law of mass conservation was applied to develop computer software with a view to analyzing the major preliminary economic indexes of industrial solar drying in both developed and rapidly developing economy. The present work used the life cycle cost method to investigate the solar process economics. In the paper three major geographical locations in Nigeria (i.e. Ibadan, Kano and Port Harcourt) were selected and their respective economic appraisal was investigated. Sample simulations revealed that, at a realistic initial moisture content of 30 (\% wet basis) of the agricultural produce, economic analysis of over 20 years shows that recommended solar collector area of $85.46 \mathrm{~m}^{2}, 80.71$ $\mathrm{m}^{2}$ and $75.96 \mathrm{~m}^{2}$ supplied about $67 \%, 88 \%$ and $55.8 \%$ of the annual energy needed for Ibadan, Kano and Port-Harcourt respectively.
\end{abstract}

\section{Keywords}

Industrialization, Platform, Pre-Visibility, Software, Economic

\section{Introduction}

The Sun is the largest source of energy in the solar system and it has the potential to supply all the energy

${ }^{*}$ Corresponding author.

How to cite this paper: Adeaga, O.A., Dare, A.A., Odunfa, K.M. and Ohunakin, O.S. (2015) Modeling of Solar Drying Economics Using Life Cycle Savings (L.C.S) Method. Journal of Power and Energy Engineering, 3, 55-70.

http://dx.doi.org/10.4236/ipee.2015.38006 
requirement of the earth. Its economic potential for any country however depends on a specific location and locality. Solar energy is the most abundant energy source in the solar system. Despite the abundance of this energy, little use is being made of it in most part of the world. This could be attributed to the initial high cost of solar energy technologies, although on a life cycle costing basis, it is generally competitive with other energy technologies where a level playing field is provided and environmental cost is considered. Solar system applications are found in different facet of life. These include space heating, water heating, industrial/domestic cooking, drying of agricultural products, solar cooling and photovoltaic generation of electricity [1].

\subsection{Why Solar Drying?}

The energy from the sun reaching the earth's atmosphere amounts to about $1.395 \mathrm{~kW} / \mathrm{m}^{2}$. This amount is only $1 / 10^{10}$ of the actual energy released by the sun. Out of this energy, $23 \%$ are used as source of hydrological cycles and photosynthesis in plants, $47 \%$ are absorbed by the atmosphere, land and ocean and are converted to long wave radiation (terrestrial radiation) and $30 \%$ are reflected and scattered back into space [2]. The use of solar dryers represents an alternative to the traditional open sun drying in developing countries. It satisfies several conditions such as fast processing, better quality of product, low energy demand and non-contaminating energy source. The main disadvantages of solar dryers are the limited time of solar radiation and the short season of harvesting of many agricultural products. Several designs of solar dryers have been proposed for use in developing countries. It has been concluded that to meet the increasing demands for food preservation in developing countries, simple, cheap but efficient solar dryers should be developed where forced convection and supplementary heat are applied [3].

The drying potential in a cabinet drying bed can be employed when air is first dehumidified and then employed for drying of agricultural produce in an attached dryer. The proposed solar drying installation in this work is a coupling of solar collector, auxiliary energy source, and solar dryer of forced-convection type. The processes of mass and heat transfer in these units are simulated. The drying kinetics in a fixed-bed assumes a non-isothermal non-trace plug flow system with some basic variables [4]. One main reason for considering solar is due to its environmental friendliness, as it does not give out any form of environmental pollution, like smoke which characterizes the conventional fossil fuel heater. It also runs smoothly and quietly. This is because it has no mechanical moving part [5]. It also means that wear and tear in solar systems is relatively small, if not totally eliminated [4]. The environmental benefit of solar application also includes no global-warming potential associated as in conventional drying systems with fossils fuels with increasing fossil fuel prices opting for solar system in order to meet the heat energy requirement will save fuel costs and also, it is economically competitive on a life cycle costing basis [4].

\subsection{Significance of Life Cycle Savings Method}

Solar energy devices and application are generally considered to be relatively new to the underdeveloped and developing nations of the world. Solar processes are generally characterized by high investment cost and low operating costs. Thus the basic economic problem is one comparing initial known investment with estimated future operating costs. Most solar energy processes require an auxiliary (i.e., conventional) energy source so that the system includes both solar and conventional equipment and the annual loads are met by a combination of the sources [2]. The Life Cycle Savings Method is a type of solar economic analysis of approach that takes the following into account 1) time value of money 2) detailed consideration of the complete range of costs 3) design criteria and variation in design factors.

\subsection{Cost of Solar Energy Delivery}

The cost of any energy delivering process includes all items of hardware and labour that are involved in installing the equipment, plus the operating expenses [6]. Factors that may be taken into consideration includes interest on borrowed money, property tax and income tax. Property tax and income tax may not be applicable in a country like Nigeria also the equipment resale value, maintenance insurance, fuel and other operating expenses should be taken into consideration.

Installed cost of solar equipment can be shown to be sum of two terms [3];

1) $C_{A}=$ total area dependent cost $(\mathrm{N})$

2) $C_{E}=$ total cost of equipment which is independent of the collector area $(\mathrm{N})$ 
Therefore $C_{s}=C_{A} \times A_{C}+C_{E}$

where, $C_{s}=$ total cost of installed solar energy equipment $(\mathrm{N}), A_{c}=$ collector area $\left(\mathrm{m}^{2}\right)$

The total area dependent cost, $C_{A}$ includes costs such as the purchase and installation of collector and a portion of storage cost. The area independent cost $C_{E}$ includes items like controls and bringing the construction erection equipment to site. Operating cost that are associated with solar process include cost of auxiliary energy, energy cost for operating fans/blower (this energy is often termed parasitic energy and should be minimized by careful design, extra insurance exists on solar equipment, maintenance etc.

\subsection{Economic Figures of Merit}

Some of the criteria proposed and used for evaluating and optimizing economics of solar energy systems are:

\subsubsection{Least Cost Energy (LCE)}

This is a reasonable figure of merit if solar energy is the only energy resource. The system with the least cost can be defined as that showing the minimum owing cost over the life of the system.

\subsubsection{Life Cycle Cost (L.C.C.)}

This is the sum of all the cost associated with an energy delivering system over its lifetime or over a selected period of analysis. This method includes inflation when estimating the future expenses.

\subsubsection{Life Cycle Savings (L.C.S)}

It is also known as the net present worth and it is defined as the difference between the life cycle of conventional fuel (only system and life cycle cost of the solar plus auxiliary energy system).

\subsubsection{Annualized Life Cycle Cost (ALCC)}

This is the average yearly outflow of money (cash flow).

\subsubsection{Pay-Back Time}

This have many definitions but in this paper, it is taken to be the time needed for the cumulative savings to equal the total initial investment, i.e., how long it takes to get investment back by saving fuel.

\section{Methodology Solar System Cost Analysis}

In the mathematical model formed, the annual cost for both solar and non-solar system to meet energy need can be expressed as [2];

$$
\begin{aligned}
\text { Yearly Cost }= & \text { Mortgage payment }+ \text { Fuel expense }+ \text { Maintenance and Insurance } \\
& + \text { Parasitic energy cost }+ \text { Property tax }- \text { Income tax savings }
\end{aligned}
$$

For income producing installation [2];

$$
\begin{array}{r}
\text { Income tax savings }=\text { Effective tax ratex }(\text { Interest payment })+\text { Property tax }+ \text { Fuel expense } \\
+ \text { Maintenanceand insurance }+ \text { Parasitic energy cost }+ \text { Depreciation } \\
\text { Effective taxrate }=\text { Federal rate } \times \text { State tax }- \text { Federal tax-statetax } \\
\text { Solar savings }=\text { Cost of conventional energy }- \text { Cost of solar energy }
\end{array}
$$

With this savings concept, it is only necessary to estimate the incremental cost of installing solar system because the solar system may have some equipment which is also common to the conventional non solar system. For example the auxiliary furnace and much of the duct work or plumbing in solar system are often the same as would be for a non-solar system. Therefore, solar savings can be rewritten as expressed below [2];

Solar savings $=$ Fuel saving - Incremental Mortgage payment - Incremental insurance andmaintenance

- Incremental parasitic energy cost + Tax saving

For income producing system [2]; 
Income tax rate $=$ Effectiveness tax rate $\times($ incremental interest payment + Incremental property tax

$$
\text { + Incremental maintenanceand insurance + Incrementalparasitic energy cost - Valueof fuel saved) }
$$

Fuel saved is a negative tax deduction since a business already deducts fuel expenses, therefore, value of fuel saved is a taxable income [2].

\subsection{Discounting of Future Cost: Inflation}

An approach to solar process economics is to use life cycle cost method that takes into account all future costs. The method provides a means of comparison of future costs with present costs. This can be done by discounting all anticipated costs to the common basis of present worth (or present value), that is, what would have been invested today, at the best alternative investment rate to have the funds available in the future to meet all anticipated expenses. The reason that cash flow must be discounted lies in the time value of money [2].

\subsubsection{Present Worth (PW)}

The relationship for determining the present worth of an amount " $A$ " needed " $N$ " (usually years) in future, with a market discount rate of " $d$ " (present per time period) is [2];

$$
\mathrm{PW}=\frac{A}{(1+d)^{N}}
$$

\subsubsection{Present Worth Factor (PWF)}

If obligation reoccurs each year and inflate at a rate " $i$ " per period, a present worth factor, PWF, of " $N$ " such payment can be found by using the following relationship [7];

$$
\operatorname{PWF}(N, i, d)= \begin{cases}\frac{1}{(d-i)}\left[1-\left[\frac{1+i}{1+d}\right]^{N}\right] & \text { for } i \neq d \\ N(1+i), & \text { for } i=d\end{cases}
$$

\subsection{The Computer Program}

The computer program makes use of the metrological data to design the solar collector. The program attempts to obtain a collector area which is capable of supplying the whole annual air heating load based on the size of a single solar module which is also a variable. Although the attainment of this state might not be practically possible as there will always be some period of cloudiness, but as the number of solar modules increases the annual fraction by solar also increases. The economic analysis is performed using the life cycle savings method. By considering the life cycle saving of the different collector size (or area) and their corresponding annual solar fraction by solar, the economically optimum collector size can therefore be selected. If reducing cost is to be considered, the optimum collector is often the one with the highest solar savings. The database contains the global radiation and the extraterrestrial solar radiation, average sunshine hours, and average relative humidity of 10 different locations in Nigeria. The database also contains properties of air as the working fluid and also that of steam. Other data in the data base are monthly averaged ambient temperature of each location, the geographical position and their monthly averaged wind speed. The database also contains data on the materials that could be used in constructing the solar collector, thereby providing the users with a choice of materials and hence cost flexibility. The program gives room for adding, deleting or editing the data concerning any location. However, additional materials which could be used in constructing the collector can also be added to the database but with the required material properties.

\section{Results and Discussions}

The simulation software was used for investigation with different thermo properties of air as fluid, locations etc., and results were obtained for 50,000 kg of agricultural produce per month. Table 1 presents the input data/parameters needed for simulation of the selected locations i.e. Ibadan, except that the location name needs to be 
edited each time there is change in location. The input data are kept in input data file within the computer program. Table 2 shows how monthly heat load and the total fraction of 0.667 supplied by solar energy varies in a year for Ibadan location. Table 3 presents the input necessary for the cost analysis for the three locations since cost is cost everywhere except cost differ in value. Table 4 gives the analysis of solar savings of 1,146,112,170 of currency unit, as to which was made through solar installation for twenty years in Ibadan location while given room for the many economic figures of merit. Table 5 is another input parameter table but know for Kano location. Table 6 shows the same thing as Table 2 but with 0.88 as the fraction of solar energy supplied know for Kano location. However Table 7 does the same as Table 3 with solar worth of savings of 17,764,928.49 of currency unit, for Kano. Table 8 does the same as Table 1 and Table 9 has 0.558 as the fraction of energy supplied by solar and Table 10 presents the solar savings over 20 years as 9,269,740.77 of currency unit, for Port Harcourt location. Both tables and figures shows that the overall cost of solar equipment and installation for locations with higher sunshine hours are lesser while the solar savings increases with time but later remain stable after some years. Most agricultural produce exhibit about 25\% - 30\% initial moisture content (wet-basis) before they are solar dried [8]. When decreasing initial moisture content, i.e. $50 \%, 40 \%, 30 \%, 20 \%$ (wet basis) were used in the simulation, the fraction of energy supplied by solar increased gradually. The required collector area in, $\mathrm{m}^{2}$, consequently reduced, and hence a reduction in the overall solar dryer cost [8]. The lower the initial moisture content, of the produce, the higher the energy supplied by solar, and also the higher the fraction of energy

Table 1. Data/parameters input for Ibadan location.

\begin{tabular}{|c|c|c|}
\hline & Data Input & \\
\hline 1 & Location Name: & Ibadan \\
\hline 2 & longitude: & 3.90 East \\
\hline 3 & Latitude: & 7.43 North \\
\hline 4 & Design Type: & Industrial \\
\hline 5 & Ground reflectance: & 0.2 \\
\hline 6 & Cover Material: & Glass \\
\hline 7 & Number of Covers: & 1 \\
\hline 8 & Plate Material: & “Copper Black” on copper \\
\hline 9 & Insulating Material: & Blanket, mineral fiber \\
\hline 10 & Collector Fluid: & Air \\
\hline 11 & Glazing thickness: & $20 \mathrm{~mm}$ \\
\hline 12 & Plate Thickness & $50 \mathrm{~mm}$ \\
\hline 13 & Plate to cover spacing: & $70 \mathrm{~mm}$ \\
\hline 14 & Air channel depth: & $30 \mathrm{~mm}$ \\
\hline 15 & Air Mass flow rate: & $0.3 \mathrm{~kg} / \mathrm{s}$ \\
\hline 16 & Surface azimuth: & $0^{\circ}$ \\
\hline 17 & Collector Slope & $15^{\circ}$ \\
\hline 18 & Insulation back thickness: & $70 \mathrm{~mm}$ \\
\hline 19 & Insulation edge thickness: & $30 \mathrm{~mm}$ \\
\hline 20 & Collector unit width: & $1.258 \mathrm{~m}$ \\
\hline 21 & Collector unit length: & $1.258 \mathrm{~mm}$ \\
\hline 22 & Mass of stock: & $50,000 \mathrm{~kg}$ per month \\
\hline 23 & Initial Moisture Content: & $30 \%$ (\% wet basis) \\
\hline 24 & Final Moisture Content: & $15 \%$ (\% wet basis) \\
\hline 25 & Crop Safe Drying Temperature: & $58^{\circ} \mathrm{C}$ \\
\hline 26 & Air Temperature After Dying: & $32^{\circ} \mathrm{C}$ \\
\hline 27 & Equilibrum Relative Humidity: & 80 \\
\hline
\end{tabular}


Table 2. Analysis of solar load output for Ibadan location.

\begin{tabular}{cccc}
\hline & & Analysis Output & \\
\hline Month & Monthly Heat Load & Energy Supply by Solar (MJ) & Fraction by Solar \\
\hline January & $21,405.882$ & $16,541.886$ & 0.733 \\
February & $21,405.882$ & $16,025.498$ & 0.749 \\
March & $21,405.882$ & $16,912.701$ & 0.79 \\
April & $21,405.882$ & $14,973.431$ & 0.7 \\
May & $21,405.882$ & $14,323.407$ & 0.669 \\
June & $21,405.882$ & $12,066.937$ & 0.564 \\
July & $21,405.882$ & $10,294.018$ & 0.481 \\
August & $21,405.882$ & 9835.477 & 0.459 \\
September & $21,405.882$ & $11,461.054$ & 0.535 \\
October & $21,405.882$ & $15,391.858$ & 0.719 \\
November & $21,405.882$ & $16,532.451$ & 0.772 \\
December & $21,405.882$ & $16,864.141$ & 0.788 \\
Total & $\mathbf{2 5 6 , 8 7 0 . 5 8 8}$ & $\mathbf{1 7 1 , 2 2 2 . 8 5 9}$ & $\mathbf{0 . 6 6 7}$ \\
\hline
\end{tabular}

Table 3. Cost analysis input parameters for Ibadan, Kano and Port Harcourt location.

\begin{tabular}{llc}
$\mathbf{1}$ & Annual mortgage interest rate (\%100): & $\mathbf{0 . 1 4}$ \\
$\mathbf{2}$ & Term of mortgage (Years) & 20 \\
$\mathbf{3}$ & Down payment (as fraction of investment \%100): & 0.1 \\
$\mathbf{4}$ & Collector area dependent costs (Monetary unit per m²): & 15,000 \\
$\mathbf{5}$ & Area Independent costs (Monetary unit): & 20,000 \\
$\mathbf{6}$ & Present cost of solar backup system fuel (Monetary unit per Giga Joule): & 1280 \\
$\mathbf{7}$ & Present cost of conventional system fuel (Monetary unit per Giga Joule) & 1280 \\
$\mathbf{8}$ & Efficiency of solar backup furnace (\%100): & 0.7 \\
$\mathbf{9}$ & Efficiency of conventional system furnace (\%100): & 0.7 \\
$\mathbf{1 0}$ & Property tax rate as fraction of investment (\%100): & 0 \\
$\mathbf{1 1}$ & Effective income tax bracket (\%100): & 0 \\
$\mathbf{1 2}$ & Extra ins., maint. \& parasitic costs (as fraction of investment \%/100): & 0.1 \\
$\mathbf{1 3}$ & General inflation rate per year (\%/100): & 0.165 \\
$\mathbf{1 4}$ & Solar backup fuel inflation rate per year (\%/100): & 0.2 \\
$\mathbf{1 5}$ & Conventional system fuel inflation rate per year (\%/100) & 0.2 \\
$\mathbf{1 6}$ & Discount rate (after tax return on best alternative investment \%/100): & 0.8 \\
$\mathbf{1 7}$ & Term of Economic analysis (Years): & 20 \\
$\mathbf{1 8}$ & Depreciation lifetime (Years) & 20 \\
$\mathbf{1 9}$ & Salvage value (as fraction of investment \%/100) & 0.2 \\
$\mathbf{2 0}$ & Market Discount Rate (\%/100): & 0.08 \\
\hline
\end{tabular}

supplied by solar. Consequently, the much lower the initial moisture content the smaller the initial cost of investment, the shorter the pay-back time (years), and the lower the collector area required in $\mathrm{m}^{2}$ with all other parameters kept constant.

For Ibadan location as shown in Tables 1-4, with 50,000 kg/month of agricultural produce the average sunshine hours per month is about 159.8 hours. Therefore the drying rate will be $313 \mathrm{~kg}$ per hour. For Kano location as shown in Tables 5-7, with the same 50,000 kg per month of agricultural produce, the average sunshine hours 
Table 4. Solar savings over 20 years for Ibadan location.

\begin{tabular}{|c|c|c|c|c|c|c|c|}
\hline \multicolumn{3}{|c|}{ Collector Area $\left(\mathrm{m}^{2}\right): 85.46$} & \multicolumn{2}{|c|}{ Pay-back Time (yrs):8 } & \multicolumn{3}{|c|}{ Initial Cost of Investment: $1,325,615.30$} \\
\hline Year & $\begin{array}{l}\text { Fuel } \\
\text { Savings }\end{array}$ & $\begin{array}{c}\text { Extra Mortgage } \\
\text { Payment }\end{array}$ & $\begin{array}{c}\text { Extra Insurance, } \\
\text { Maintenance, Energy }\end{array}$ & $\begin{array}{c}\text { Extra } \\
\text { Property Tax }\end{array}$ & $\begin{array}{l}\text { Income Tax } \\
\text { Savings }\end{array}$ & $\begin{array}{l}\text { Solar } \\
\text { Savings }\end{array}$ & $\begin{array}{l}\text { Present Worth } \\
\text { of Solar Saving }\end{array}$ \\
\hline $\mathbf{0}$ & & & & & & $-132,561.53$ & $-132,561.53$ \\
\hline 1 & $154,287.98$ & $-180,134.42$ & $-132,561.53$ & 0 & 0 & $-158,407.97$ & $-146,674.05$ \\
\hline 2 & $378,501.89$ & $-180,134.42$ & $-154,434.18$ & 0 & 0 & 43,933.29 & $37,665.71$ \\
\hline 3 & $454,202.27$ & $-180,134.42$ & $-179,915.82$ & 0 & 0 & $94,152.03$ & $74,740.91$ \\
\hline 4 & $545,042.72$ & $-180,134.42$ & $-209,601.93$ & 0 & 0 & $155,306.37$ & $114,154.82$ \\
\hline 5 & $654,051.27$ & $-180,134.42$ & $-244,186.25$ & 0 & 0 & $229,730.59$ & $156,350.78$ \\
\hline 6 & $784,861.52$ & $-180,134.42$ & $-284,476.98$ & 0 & 0 & $320,250.12$ & $201,811.9$ \\
\hline 7 & $941,833.82$ & $-180,134.42$ & $-331,415.69$ & 0 & 0 & $430,283.72$ & $251,066.42$ \\
\hline 8 & $1,130,200 ' 59$ & $-180,134.42$ & $-386,099.27$ & 0 & 0 & $563,966.89$ & $304,693.76$ \\
\hline 9 & $1,356,240.7$ & $-180,134.42$ & $-449,805.65$ & 0 & 0 & $726,300.63$ & $363,331.14$ \\
\hline 10 & $1,627,488.8$ & $-180,134.42$ & $-524,023.59$ & 0 & 0 & $923,330.84$ & $427,680.83$ \\
\hline 11 & 1,952,986.6 & $-180,134.42$ & $-610,487.48$ & 0 & 0 & $1,162,364.71$ & $498,518.3$ \\
\hline 12 & 2,343,583.9 & $-180,134.42$ & $-711,217.91$ & 0 & 0 & $1,452,231.6$ & $576,701.15$ \\
\hline 13 & $2,812,300.7$ & $-180,134.42$ & $-828,568.87$ & 0 & 0 & $1,803,597.43$ & $663,179.03$ \\
\hline 14 & $3,374,760.9$ & $-180,134.42$ & $-965,282.73$ & 0 & 0 & $2,229,343.71$ & $759,004.68$ \\
\hline 15 & $4,049,713$ & $-180,134.42$ & $-1,124,554.38$ & 0 & 0 & $2,745,024.24$ & $865,346.12$ \\
\hline 16 & $4,859,655.7$ & $-180,134.42$ & $1,310,105.86$ & 0 & 0 & $3,369,415.37$ & $983,500.23$ \\
\hline 17 & $5,831,586.8$ & $-180,134.42$ & $-15,261,273.32$ & 0 & 0 & $4,125,179.03$ & $1,114,907.81$ \\
\hline 18 & $6,997,904.1$ & $-180,134.42$ & $-1,778,108.42$ & 0 & 0 & $5,039,661.29$ & $1,261,170.35$ \\
\hline 19 & 8,397,485 & $-180,134.42$ & $-2,071,496.31$ & 0 & 0 & $6,145,854.23$ & $1,424,068.57$ \\
\hline 20 & $10,076,982$ & $-180,134.42$ & $-2,413,293.2$ & 0 & 0 & $7,483,554.33$ & $1,605,583.17$ \\
\hline & & & & & Salvage Value & $265,123.06$ & $56,881.68$ \\
\hline
\end{tabular}

Table 5. Data input for Kano location.

\begin{tabular}{|cc}
\hline Data input & \\
\hline Location Name: & Kano \\
Longitude: & 8.53 East \\
Latitude: & 12.05 North \\
Design Type: & Industrial \\
Ground reflectance: & 0.2 \\
Cover Material: & Glass \\
Number of covers: & 1 \\
Plate Material: & “Copper Black” on Copper \\
Insulating Material: & Blanket, mineral fiber \\
Collector Fluid: & Air \\
Glazing thickness: & $20 \mathrm{~mm}$ \\
Plate thickness: & $50 \mathrm{~mm}$ \\
Plate to cover spacing: & $70 \mathrm{~mm}$ \\
Air channel depth: & $30 \mathrm{~mm}$ \\
Air Mass flow rate: & $0.3 \mathrm{~kg} / \mathrm{s}$ \\
\hline
\end{tabular}




\begin{tabular}{lcc} 
Continued & \\
\hline Surface azimuth: & $\mathbf{0}^{\circ}$ \\
\hline Collector slope: & $15^{\circ}$ \\
\hline Insulating back thickness: & $70 \mathrm{~mm}$ \\
Insulating edge thickness: & $30 \mathrm{~mm}$ \\
Collector unit width: & $1.258 \mathrm{~m}$ \\
Collector unit length: & $1.258 \mathrm{~mm}$ \\
Mass of stock: & $50,000 \mathrm{~kg}$ per month \\
Initial Moisture Content: & $30 \%(\%$ wet basis $)$ \\
Final Moisture Content: & $15 \%(\%$ wet basis $)$ \\
Crop Safe Drying Temperature: & $58^{\circ} \mathrm{C}$ \\
Air Temperature After Drying: & $32^{\circ} \mathrm{C}$ \\
Equilibrium Relative Humidity: & 80 \\
\hline
\end{tabular}

Table 6. Solar load analysis output for Kano location.

\begin{tabular}{cccc}
\hline \multicolumn{3}{c}{ Analysis output } \\
\hline Month & Monthly Heat Load (MJ) & Energy Supply by Solar (MJ) & Fraction by Solar \\
\hline January & $21,405.882$ & $19,035.857$ & 0.889 \\
February & $21,405.882$ & $18,485.381$ & 0.864 \\
March & $21,405.882$ & $20,734.907$ & 0.869 \\
April & $21,405.882$ & $19,074.077$ & 0.891 \\
May & $21,405.882$ & $19,237.052$ & 0.899 \\
June & $21,405.882$ & $17,697.574$ & 0.827 \\
July & $21,405.882$ & $17,159.141$ & 0.802 \\
August & $21,405.882$ & $16,010.117$ & 0.748 \\
September & $21,405.882$ & $18,760.925$ & 0.876 \\
October & $21,405.882$ & $21,319.315$ & 0.996 \\
November & $21,405.882$ & $19,688.957$ & 0.92 \\
December & $21,405.882$ & $18,798.1$ & 0.878 \\
Total & $\mathbf{2 5 6 , 8 7 0 . 5 8 8}$ & $\mathbf{2 2 6 , 0 0 1 . 4 0 4}$ & $\mathbf{0 . 8 8}$ \\
\hline
\end{tabular}

Table 7. Solar savings over 20 years for Kano location.

\begin{tabular}{cccccccc}
\hline & Collector Area $\left(\mathbf{m}^{\mathbf{2}}\right) \mathbf{8 0 . 7 1}$ & \multicolumn{2}{c}{ Pay-back Time (yrs):6 } & \multicolumn{2}{c}{ Initial Cost of Investment: 1,254,399.92 } \\
\hline Year & Fuel Savings & $\begin{array}{c}\text { Extra Mortgage } \\
\text { Payment }\end{array}$ & $\begin{array}{c}\text { Extra Insurance, } \\
\text { Maintenance, Energy }\end{array}$ & $\begin{array}{c}\text { Extra } \\
\text { Property Tax }\end{array}$ & $\begin{array}{c}\text { Income } \\
\text { Tax }\end{array}$ & $\begin{array}{c}\text { Solar } \\
\text { Savings }\end{array}$ & $\begin{array}{c}\text { Present Worth } \\
\text { of Solar Saving }\end{array}$ \\
\hline $\mathbf{0}$ & & & & & & $-125,440$ & $-125,439.99$ \\
$\mathbf{1}$ & $53,064.45$ & $-170,457.15$ & $-125,439.99$ & 0 & 0 & $-242,833$ & $-224,845.08$ \\
$\mathbf{2}$ & $499,970.12$ & $-170,457.15$ & $-146,137.59$ & 0 & 0 & $183,375.4$ & $157,214.84$ \\
$\mathbf{3}$ & $599,964.15$ & $-170,457.15$ & $-170,250.29$ & 0 & 0 & $259,256.7$ & $205,806.33$ \\
$\mathbf{4}$ & $719,956.98$ & $-170,457.15$ & $-198,341.59$ & 0 & 0 & $351,158.2$ & $258,111.79$ \\
$\mathbf{5}$ & $863,948.37$ & $-170,457.15$ & $-231,067.95$ & 0 & 0 & $462,423.3$ & $314,717.51$ \\
$\mathbf{6}$ & $1,036,738.05$ & $-170,457.15$ & $-269,194.17$ & 0 & 0 & $597,086.7$ & $376,265.93$ \\
$\mathbf{7}$ & $1,244,085.66$ & $-170,457.15$ & $-313,611.2$ & 0 & 0 & $760,017.3$ & $443,462.8$ \\
$\mathbf{8}$ & $1,492,902.79$ & $-170,457.15$ & $-365,357.05$ & 0 & 0 & $957,088.6$ & $517,085.18$ \\
$\mathbf{9}$ & $1,791,483.35$ & $-170,457.15$ & $-425,640.97$ & 0 & 0 & $1,195,385$ & $597,990.23$ \\
\hline
\end{tabular}




\section{Continued}

$\begin{array}{lccccccc}\mathbf{1 0} & \mathbf{2 , 1 4 9 , 7 8 0 . 0 1} & -\mathbf{1 7 0 , 4 5 7 . 1 5} & \mathbf{- 4 9 5 , 8 7 1 . 7 3} & \mathbf{0} & \mathbf{0} & \mathbf{1 , 4 8 3 , 4 5 1} & \mathbf{6 8 7 , 1 2 4 . 9 1} \\ \mathbf{1 1} & 2,579,736.02 & -170,457.15 & -577,690.56 & 0 & 0 & 1,831,588 & 785,536.83 \\ \mathbf{1 2} & 3,095,683.22 & -170,457.15 & -673,009.5 & 0 & 0 & 2,252,217 & 894,386.19 \\ \mathbf{1 3} & 3,714,819.87 & -170,457.15 & -784,056.07 & 0 & 0 & 2,760,307 & 1,014,959.03 \\ \mathbf{1 4} & 4,457,783.84 & -170,457.15 & -913,425.32 & 0 & 0 & 3,373,901 & 1,148,681.97 \\ \mathbf{1 5} & 5,349,340.61 & -170,457.15 & -1,064,140.5 & 0 & 0 & 4,114,743 & 1,297,138.59 \\ \mathbf{1 6} & 6,419,208.73 & -170,457.15 & -1,239,723.68 & 0 & 0 & 5,009,028 & 1,462,087.5 \\ \mathbf{1 7} & 7,703,050.47 & -170,457.15 & -1,444,278.09 & 0 & 0 & 6,088,315 & 1,645,482.58 \\ \mathbf{1 8} & 9,243,660.57 & -170,457.15 & -1,682,583.98 & 0 & 0 & 7,390,619 & 1,849,495.34 \\ \mathbf{1 9} & 11,092,392.68 & -170,457.15 & -1,960,210.33 & 0 & 0 & 8,961,725 & 2,076,539.84 \\ \mathbf{2 0} & 13,310,871.22 & -170,457.15 & -2,283,645.04 & 0 & 0 & 10,856,769 & 2,329,300.33 \\ & & & & & \text { Salvage } & \text { 250,880 } & 53,825.85 \\ & & & & & & \text { Value } & \text { Total Present Worth of Savings }=\end{array}$

Table 8. Data Input for Port Harcourt location.

\begin{tabular}{|c|c|c|}
\hline & Data Input & \\
\hline 1 & Location Name: & Port Harcourt \\
\hline 2 & longitude: & 7.02 East \\
\hline 3 & Latitude: & 4.86 North \\
\hline 4 & Design Type: & Industrial \\
\hline 5 & Ground reflectance: & 0.2 \\
\hline 6 & Cover Material: & Glass \\
\hline 7 & Number of Covers: & 1 \\
\hline 8 & Plate Material: & “Copper Black” on copper \\
\hline 9 & Insulating Material: & Blanket, mineral fiber \\
\hline 10 & Collector Fluid: & Air \\
\hline 11 & Glazing thickness: & $20 \mathrm{~mm}$ \\
\hline 12 & Plate Thickness & $50 \mathrm{~mm}$ \\
\hline 13 & Plate to cover spacing: & $70 \mathrm{~mm}$ \\
\hline 14 & Air channel depth: & $30 \mathrm{~mm}$ \\
\hline 15 & Air Mass flow rate: & $0.3 \mathrm{~kg} / \mathrm{s}$ \\
\hline 16 & Surface azimuth: & $0^{\circ}$ \\
\hline 17 & Collector Slope & $15^{\circ}$ \\
\hline 18 & Insulation back thickness: & $70 \mathrm{~mm}$ \\
\hline 19 & Insulation edge thickness: & $30 \mathrm{~mm}$ \\
\hline 20 & Collector unit width: & $1.258 \mathrm{~m}$ \\
\hline 21 & Collector unit length: & $1.258 \mathrm{~mm}$ \\
\hline 22 & Mass of stock: & $50,000 \mathrm{~kg}$ per month \\
\hline 23 & Initial Moisture Content: & $30 \%$ (\% wet basis) \\
\hline 24 & Final Moisture Content: & $15 \%$ (\% wet basis) \\
\hline 25 & Crop Safe Drying Temperature: & $58^{\circ} \mathrm{C}$ \\
\hline 26 & Air Temperature After Dying: & $32^{\circ} \mathrm{C}$ \\
\hline 27 & Equilibrum Relative Humidity: & 80 \\
\hline
\end{tabular}


Table 9. Analysis of solar load output for Port Harcourt location.

\begin{tabular}{cccc}
\hline & & Analysis Output & \\
\hline Month & Monthly Heat Load & Energy Supply by Solar (MJ) & Fraction by Solar \\
\hline January & $21,405.882$ & $14,080.138$ & 0.658 \\
February & $21,405.882$ & $13,458.763$ & 0.629 \\
March & $21,405.882$ & $13,510.334$ & 0.631 \\
April & $21,405.882$ & $12,634.204$ & 0.59 \\
May & $21,405.882$ & $11,910.251$ & 0.556 \\
June & $21,405.882$ & 9519.288 & 0.445 \\
July & $21,405.882$ & 9149.952 & 0.427 \\
August & $21,405.882$ & 9567.973 & 0.447 \\
September & $21,405.882$ & $10,126.62$ & 0.473 \\
October & $21,405.882$ & $12,250.308$ & 0.572 \\
November & $21,405.882$ & $13,074.296$ & 0.611 \\
December & $21,405.882$ & $13,996.183$ & 0.654 \\
Total & $\mathbf{2 5 6 , 8 7 0 . 5 8 8}$ & $\mathbf{1 4 3 , 2 7 8 . 3 1 1}$ & $\mathbf{0 . 5 5 8}$ \\
\hline
\end{tabular}

Table 10. Solar savings over 20 years for Port Harcourt location.

\begin{tabular}{|c|c|c|c|c|c|c|c|}
\hline \multicolumn{3}{|c|}{ Collector Area $\left(\mathrm{m}^{2}\right): 75.96$} & \multicolumn{2}{|c|}{ Pay-back Time (yrs):8 } & \multicolumn{3}{|c|}{ Initial Cost of Investment: $1,183,184.54$} \\
\hline Year & $\begin{array}{c}\text { Fuel } \\
\text { Savings }\end{array}$ & $\begin{array}{l}\text { Extra } \\
\text { Mortgage } \\
\text { Payment }\end{array}$ & $\begin{array}{l}\text { Extra Insurance, } \\
\text { Maintenance, } \\
\text { Energy }\end{array}$ & $\begin{array}{c}\text { Extra } \\
\text { Property } \\
\text { Tax }\end{array}$ & $\begin{array}{l}\text { Income Tax } \\
\text { Savings }\end{array}$ & $\begin{array}{l}\text { Solar } \\
\text { Savings }\end{array}$ & $\begin{array}{l}\text { Present Worth } \\
\text { of Solar Saving }\end{array}$ \\
\hline $\mathbf{0}$ & & & & & & $-118,318.45$ & $-118,318.45$ \\
\hline 1 & $205,427.8$ & $-160,779.87$ & $-118,318.45$ & 0 & 0 & $-73,670.53$ & $-68,213.45$ \\
\hline 2 & $317,134.1$ & $-160,779.87$ & $-137,841$ & 0 & 0 & $18,513.23$ & $15,872.11$ \\
\hline 3 & $380,560.92$ & $-160,779.87$ & $-160,584.76$ & 0 & 0 & $59,196.29$ & 46,991.92 \\
\hline 4 & $456,673.11$ & $-160,779.87$ & $-187,081.25$ & 0 & 0 & $108,811.99$ & $79,980.06$ \\
\hline 5 & $548,007.73$ & $-160,779.87$ & $-217,949.66$ & 0 & 0 & $169,278.2$ & $115,207.9$ \\
\hline 6 & $657,609.28$ & $-160,779.87$ & $-253,911.35$ & 0 & 0 & $242,918.06$ & $153,079.58$ \\
\hline 7 & $789,131.13$ & $-160,779.87$ & $-295,806.72$ & 0 & 0 & $332,544.54$ & $194,036.54$ \\
\hline 8 & $946,957.36$ & $-160,779.87$ & $-344,614.83$ & 0 & 0 & $441,562.66$ & $238,562.56$ \\
\hline 9 & $1,136,348.83$ & $-160,779.87$ & $-401,476.28$ & 0 & 0 & $574,092.68$ & $287,189.27$ \\
\hline 10 & $1,363,618.9$ & $-160,779.87$ & $-467,719.86$ & 0 & 0 & $735,118.86$ & $340,502.27$ \\
\hline 11 & $1,636,342.32$ & $-160,779.87$ & $-544,893.64$ & 0 & 0 & $930,668.8$ & $399,147.9$ \\
\hline 12 & 1,963,610.78 & $-160,779.87$ & $-634,801.09$ & 0 & 0 & $1,168,029.81$ & $463,840.71$ \\
\hline 13 & 2,356,332.94 & $-160,779.87$ & $-739,543.27$ & 0 & 0 & $1,456,009.79$ & $535,371.78$ \\
\hline \multirow[t]{2}{*}{14} & 2,827,599.52 & $-160,779.87$ & $-861,567.91$ & 0 & 0 & $1,805,251.74$ & $614,617.89$ \\
\hline & $3,393,119.43$ & $-160,779.87$ & $-1,003,726.6$ & 0 & 0 & $2,228,612.94$ & $702,551.74$ \\
\hline 16 & $4,071,743.31$ & $-160,779.87$ & $-1,169,341.5$ & 0 & 0 & $2,741,621.93$ & $800,253.31$ \\
\hline 17 & $4,886,091.98$ & $-160,779.87$ & $-1,362,282.9$ & 0 & 0 & $3,363,029.24$ & $908,922.39$ \\
\hline 18 & $5,863,310.37$ & $-160,779.87$ & $-1,587,059.5$ & 0 & 0 & $4,115,470.97$ & 1,029,892.61 \\
\hline 19 & $7,035,972.44$ & $-160,779.87$ & $-1,848,924.4$ & 0 & 0 & $5,026,268.22$ & $1,164,646.98$ \\
\hline \multirow[t]{3}{*}{20} & $8,443,166.93$ & $-160,779.87$ & $-2,153,996.9$ & 0 & 0 & $6,128,390.19$ & 1,314,835.13 \\
\hline & & & & & Salvage Value & $236,636.91$ & $50,770.02$ \\
\hline & & & & & \multicolumn{3}{|c|}{ Total Present Worth of Savings = 9,269,740.77 } \\
\hline
\end{tabular}


per month is about 261.7 hours therefore the drying rate will be $191 \mathrm{~kg}$ per hour. For Port Harcourt location as shown in Tables 8-10 with the same 50,000 kg produce the average sunshine hours per month is about 118 hours. Therefore the drying rate will be $424.3 \mathrm{~kg}$ per hour. A close observation of the drying rate of Ibadan, Kano and Port Harcourt of the produce revealed close and neighbouring values. Hence, a better way is to fix the drying rate in $\mathrm{kg} / \mathrm{hr}$. or $\mathrm{kg} / \mathrm{s}$., and calculate the amount that can be dried in each location. However, the large difference between any industrial solar dryer located at Ibadan, Kano and Port Harcourt will be the initial investment cost of equipment (to include solar collectors unit area cost), the solar savings for a given period of time and the pay-back period. The total cost which include, the installation cost, the equipment cost and the operating costs and maintenance cost at Ibadan and Port Harcourt will surely be on the high side when compared to that in Kano, hence relative advantage at locations with high average sunshine hours per day to those with lesser or lower average sunshine hours per day. However, a better solar saving could be achieved with lower inflation and interest rates. Figure 1, Figure 2 and Figure 3 show that Ibadan location has moderate solar fraction and

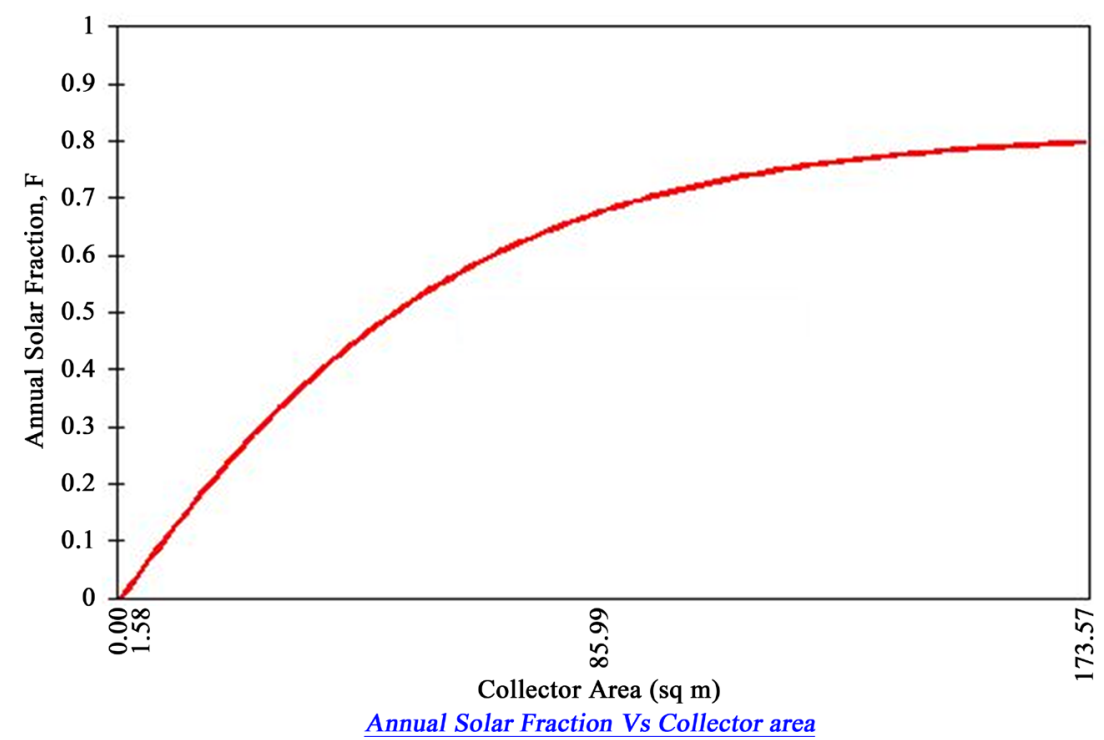

Figure 1. Annual solar fraction against collector area for Ibadan location.

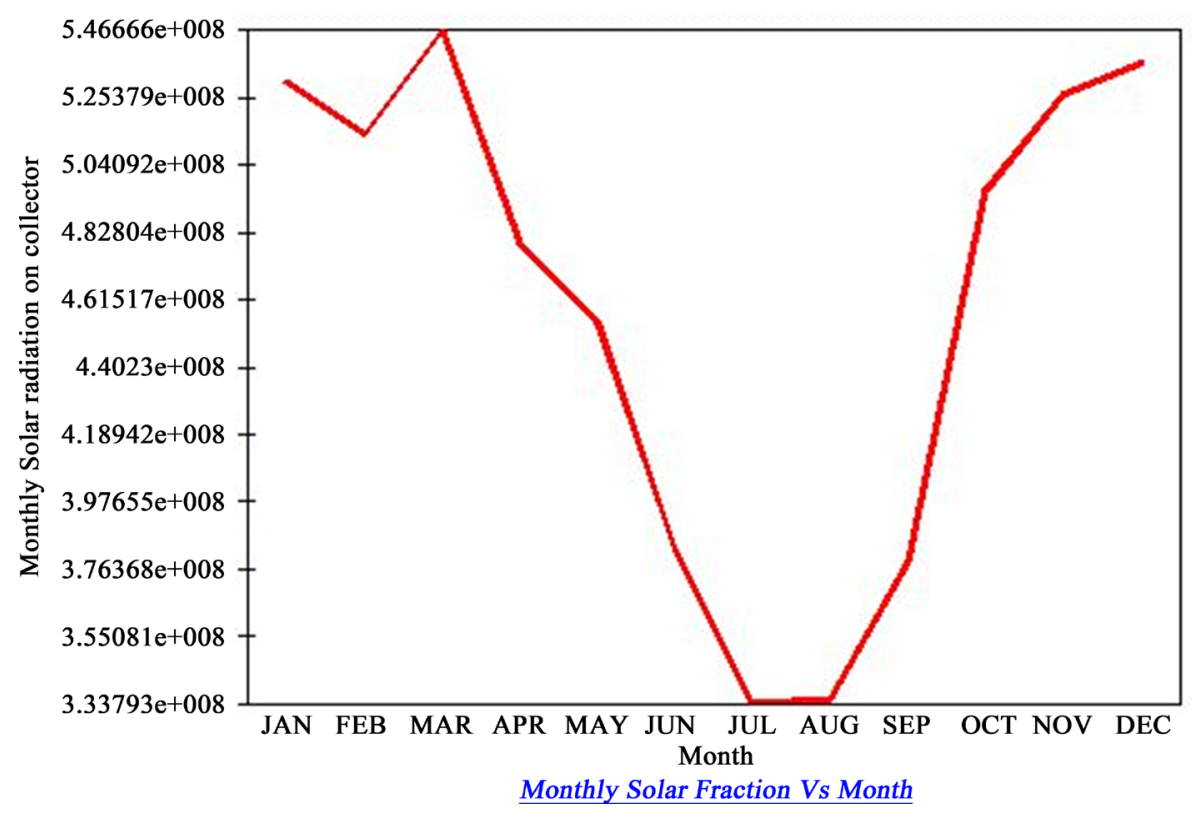

Figure 2. Monthly solar radiation on collector against month of the year for Ibadan location. 


\section{O. A. Adeaga et al.}

distribution when compared to Kano location in Figures 4-6, but for Port Harcourt from Figures 7-9 with lower solar fraction both annually and monthly. Also affecting is the air flow rate required for drying, as it was revealed during simulation, that higher air flow rates, keeping other things constant, means increase in the annual solar fraction but for larger fan/blower and consequently cost of purchase [1]. The simulation iteration stops when 1) The number of solar modules obtained can fully supply the energy needed for drying 2) when the additional energy needed is less than $1 / 100^{\text {th }}$ of the original energy supplied by the lead solar module. The simulation was done with input that represents industrial applications.

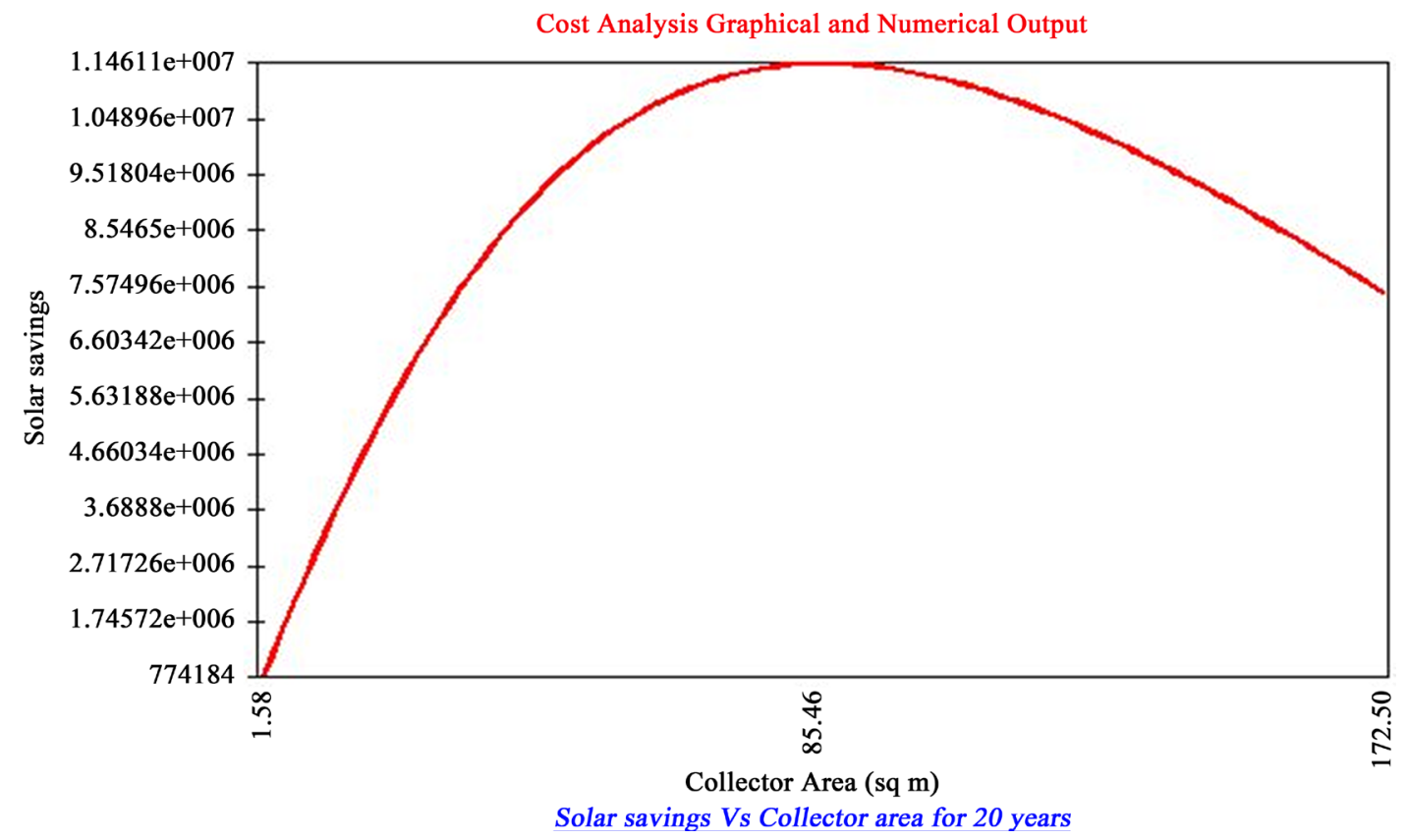

Figure 3. Solar savings against collector area for Ibadan location.

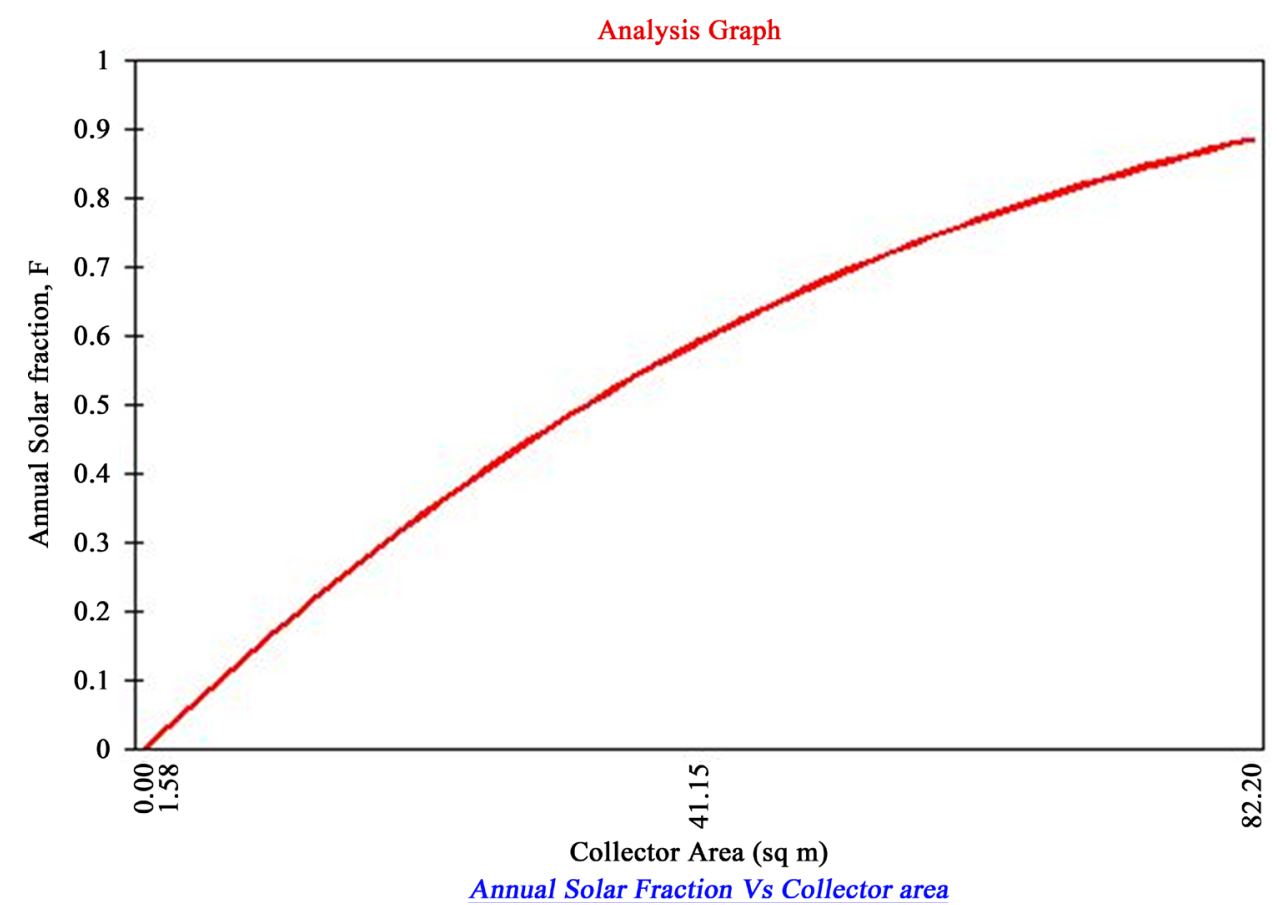

Figure 4. Annual solar fraction against collector area for Kano location. 


\section{Cost Analysis}

In developing countries like Nigeria, items like mortgage interest rate, down payment and the likes, sounds unrealistic, hence the cost analysis is recommended to be adapted. The $C_{A}$ and $C_{E}$ are area dependent cost and area

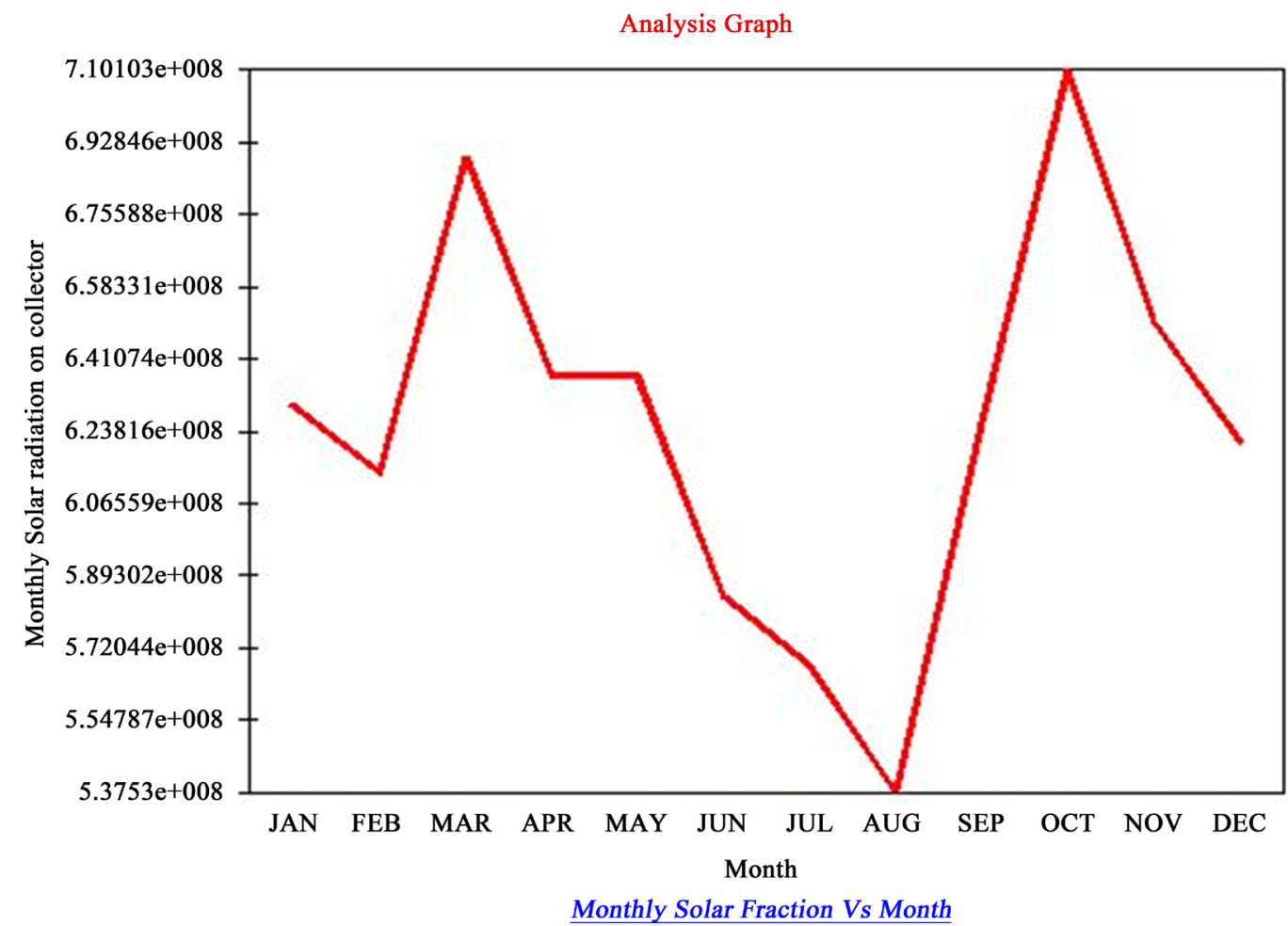

Figure 5. Monthly solar radiation on collector against month of the year for Kano location.

Cost Analysis Graphical and Numerical Output

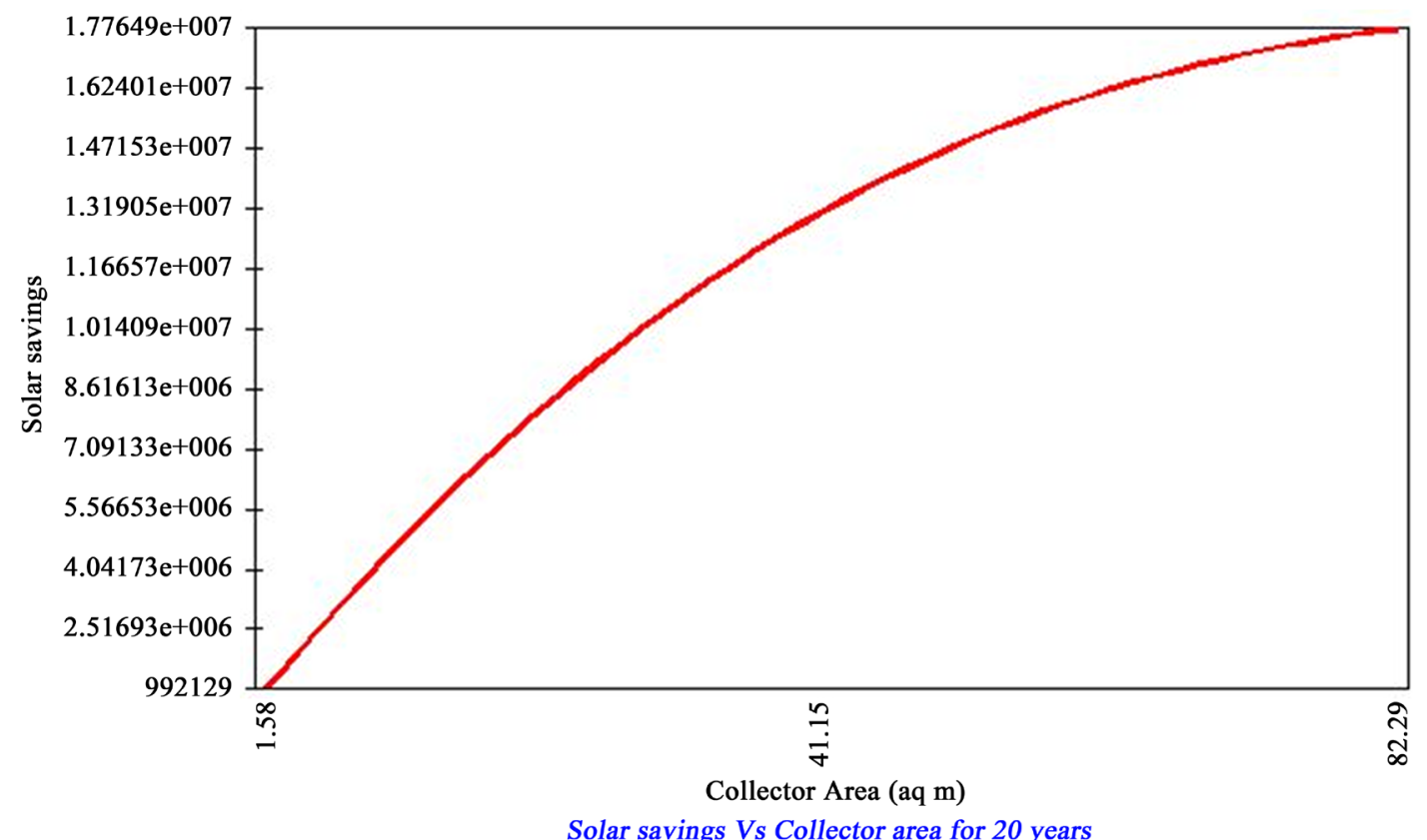

Figure 6. Solar savings against collector area for Kano location. 


\section{O. A. Adeaga et al.}

independent cost respectively and they contribute to the overall cost of the installation. Based on simulation experience, $C_{A} \approx n C_{E}$ and for industrial set up it was assumed that, $n=3$. If a smaller initial moisture content is used, the collector area required for a solar fraction supply will be smaller and hence larger $C_{A} / C_{E}$. Smaller $C_{E}$ will surely reduce Cost, $C_{s}$. Therefore the larger the ratio of $C_{A} / C_{E}$, the more reduced " $C_{s}$ " and hence, higher solar savings.

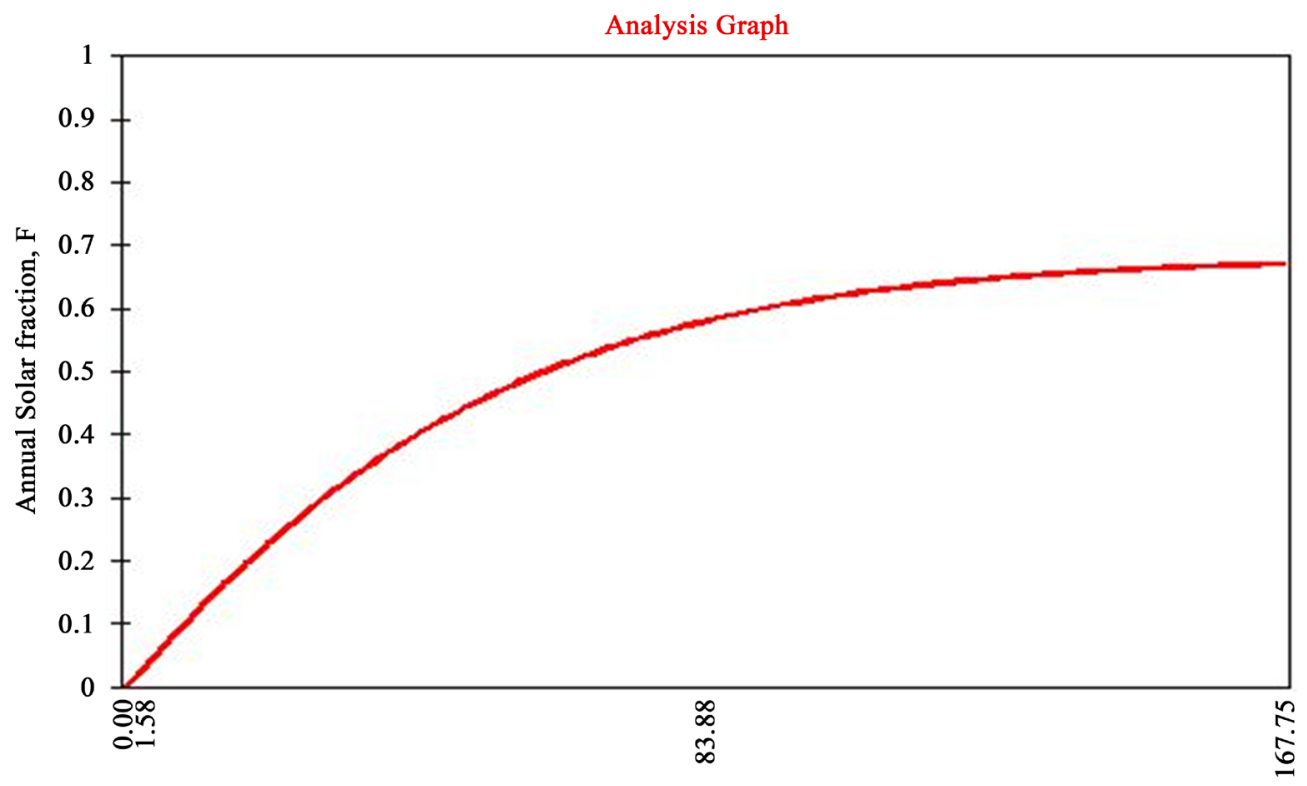

Collector Area (sq m)

Annual Solar Fraction Vs Collector area

Figure 7. Annual solar fraction against collector area for Port Harcourt location.

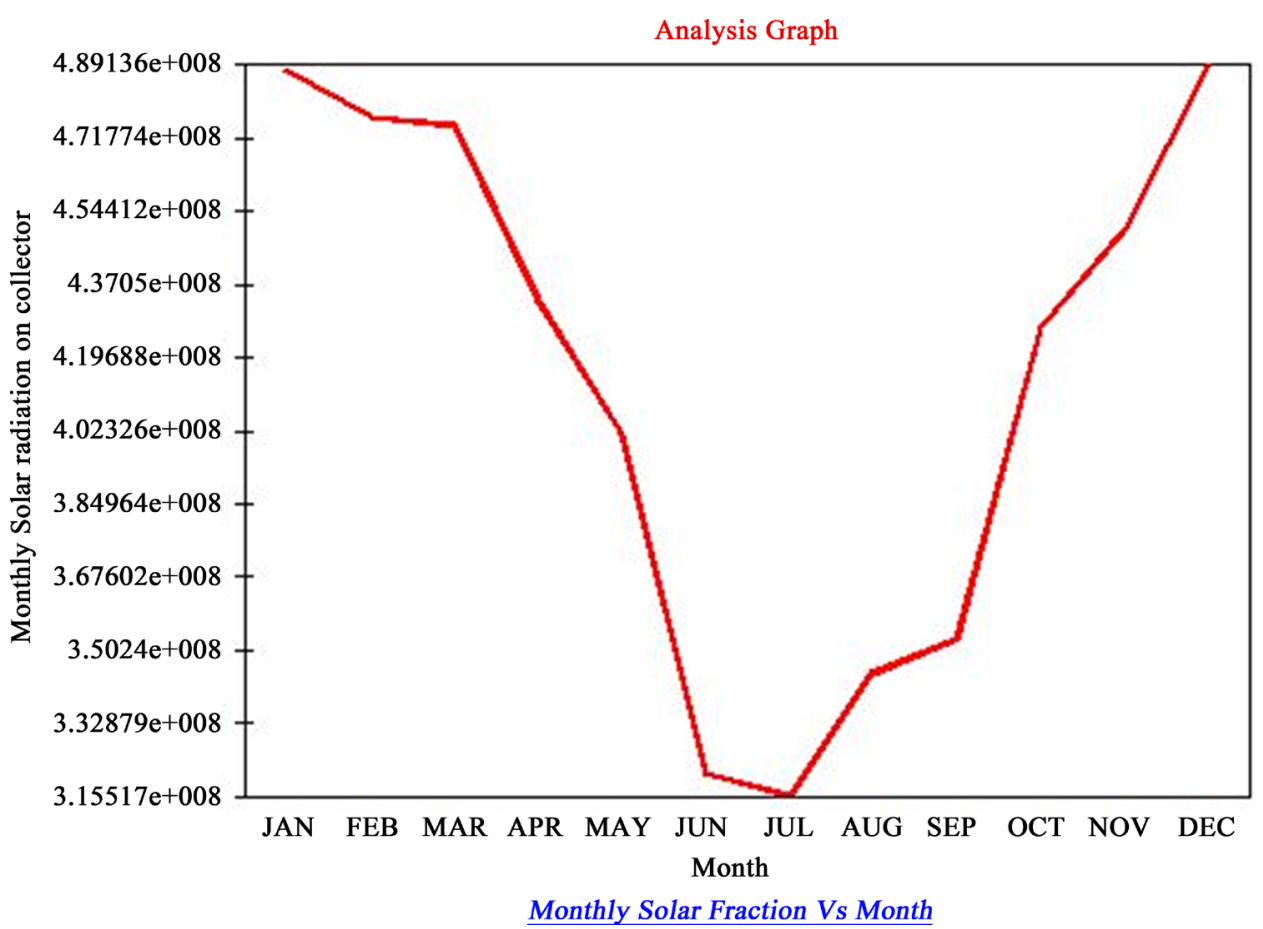

Figure 8. Monthly solar radiation on collector against month of the year for Port Harcourt location. 
Cost Analysis Graphical and Numerical Output

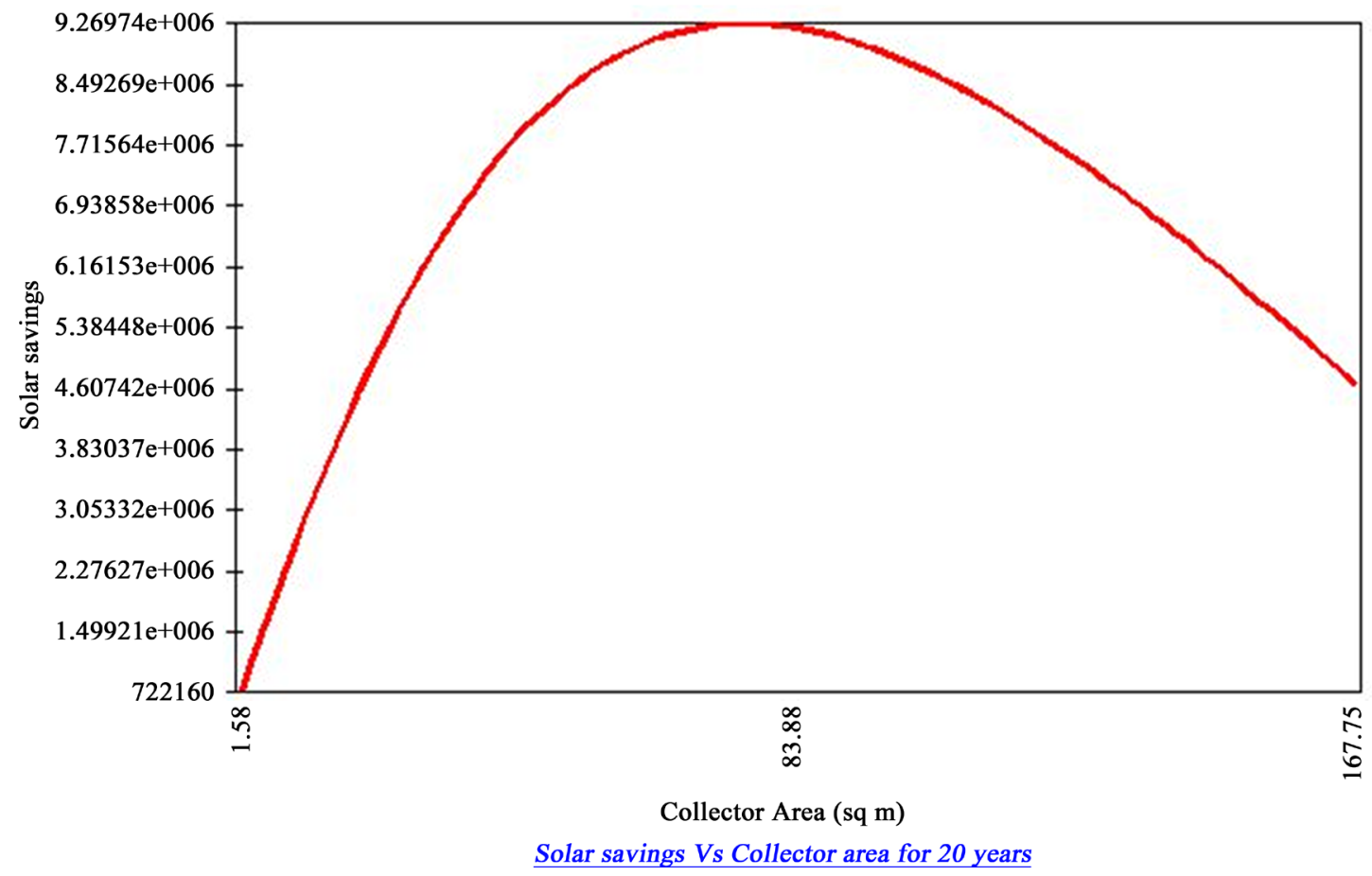

Figure 9. Solar savings against collector area for Port Harcourt location.

\section{Recommendations}

The selection of other materials for use in the design should also be based on their availability and affordability because nobody will want to buy any equipment that is too expensive and for which spare parts are not locally available. To help in performing economic analysis using this software, prices of solar air heating systems of different configurations can be obtained on the internet sites of international vendors and manufacturers. Though varieties of economic figures of merit like payback times, cash flow etc., have been proposed and applied but the life cycle costing method is sufficiently the most inclusive since it take into account any level of detail the user wishes to include even, the dynamic nature of time value of money and hence recommended. The kinetics of moisture within the agricultural produce had not been dealt with in this paper.

\section{Conclusion}

Pre-investment, investment and operating cost that may be attached with industrial solar drying processes are actually functions of different meteorological data. These data are the essentials of optimum profit when the application of Solar drying equipment becomes pragmatically imperative. Although there are many values of solar collector that could easily support profitability but the optimal collector area needs to be examined and appropriately applied. However, the study revealed that solar collector area of $85.46 \mathrm{~m}^{2}, 80.71 \mathrm{~m}^{2}$ and $75.96 \mathrm{~m}^{2}$ supplied about $67 \%$, $88 \%$ and $55.8 \%$ of the annual energy needed which are the simulated optimum solar energy value with payback period of 8 years, 6 years and 8 years and also salvage value of 265,123.06, 250,880 and 236,636.91 for Ibadan, Kano and Port-Harcourt locations respectively. Though many solar economic figures of merits are available but larger number of those methods are designed to evaluate fuel payment for an alternative or conventional process and energy supply.

\section{References}

[1] Soha, M.S. and Chandra, R. (1994) Solar Drying Systems and Their Testing Procedures: A Review. Energy Conversion and Management, 35, 219-267.

[2] Duffie, J.A. and Beckman, W.A. (1980) Solar Thermal Engineering. John Willey \& Sons Inc., Hoboken. 
[3] Fagbenle, R.O. (1993) Estimation of Diffuse Solar Radiation in Ibadan, Nigeria. International Journal of Solar Energy, 13, 145-153. http://dx.doi.org/10.1080/01425919208909781

[4] Lasode, J.A. (1994) Journal of Applied Science, Engineering and Technology, 4, 32-43.

[5] Fagbenle, R.O. (1991) On Monthly Average Daily Extraterrestrial Solar Radiation for Nigeria Latitudes. Nigeria Journal of Renewable Energy, 2, 1-8.

[6] Fagbenle, R.O. (2004-2005) Heat Transfer Lecture Note. University of Ibadan, Ibadan, 12-19.

[7] Fagbenle, R.O. (1990) Estimation of Total Solar Radiation in Nigeria Using Meteorological Data. Nigeria Journal of Renewable Energy, 1, 1-8.

[8] Otherno, H. (1993) Design Factors of Small Scale Thermo-Syphon Solar Crop Dryers. Workshop on Solar Drying, University of Accra, Accra, 2-10. 